\title{
THE INFLUENCE OF THE USE OF RECYCLED GYPSUM ON THE PROPERTIES OF GYPSUM PRODUCTS IN LABOR CONDITIONS
}

\author{
Hana Sekavováa ${ }^{a, b, *}$, Jakub Herrmann ${ }^{a}$, ZdenĚK ProšeK ${ }^{a}$, \\ Miroslav NyČ ${ }^{b}$, George Karra'A ${ }^{c}$ \\ ${ }^{a}$ Czech Technical University in Prague, Faculty of Civil Engineering, Department of Mechanics, Thákurova 7, \\ 16629 Prague 6, Czech Republic \\ ${ }^{b}$ KNAUF Praha spol. s r.o., Mladoboleslavská 949, 19700 Prague 9, Czech Republic \\ c LAVARIS s.r.o., Areál Šroubáren 43, 25266 Libčice nad Vltavou, Czech Republic \\ * corresponding author: hana.sekavova@fsv.cvut.cz
}

\begin{abstract}
The article presents the first results from research, which is deal with recycling of plaster boards and use of the resulting material. The research is carried out within the project MPO Trio č. FV30359 "Recyklace sádrokartonových desek a nová materiálová využití s přidanou hodnotou GIPSRec". The plasterboards are produced of stucco, which is calcinated of Flue Gas Desulfurization Gypsum (FGD Gypsum). There is possibility to replace a part of this stucco with recycled material. There is opportunity for saving costs for production. The question how this utilization can change the properties of the products is very important and it is necessary to find the possible improvement or deterioration. This is the objective of this research. The effect on properties was monitored on the samples which was prepared of only pure stucco and of stucco with part of recycled material. There was observed water ratio (splash test), setting times, volume changes, flexural strength, compressive strength and elasticity module.
\end{abstract}

KEYworDS: FGD gypsum, stucco, recyclation.

\section{INTRODUCTION}

The gypsum was used as a building material for thousands of years. There are references, that the gypsum occurs on buildings dated 7000 BC. The gypsum was used in ancient Egypt and Rome. Great fame has gypsum in 16th century and it is very popular material till today [1].

There are two main sources of gypsum. At first we can find several sources of natural gypsum in the world. There is only one in Czech Republic and it is situated near the Opava. This is part of Polish gypsum pan. The purity of the natural gypsum is variable and it depends on the location of mine. The purity of gypsum in the mine Kobeřice u Opavy is $60-85 \%$ [1].

Higher level of purity has gypsum from industrial operations. The syntetic gypsum is still the waste product of the other production. There are for example FGD gypsum, and gypsum generated during the chemical production [1].

The amount of the natural gypsum is limited and the amount of FGD gypsum depends on working power plants which used coal for producing of electric energy (FGD gypsum is product of wet limestone scrubbing of flue gas contains sulfur oxides - chemical reaction between limestone suspension and sulfur oxides). The plan for the future is that these power plants will end their life about year 2050, because of their service life and because of the end of coal mining [2].

It is necessary to search for the new possibilities, how to reduce the amount of gypsum, which is used for production of building material. The first way is to find the fillers and additives, which reduce the amount of stucco in production. And the second way is recycled the waste of the gypsum based products and put them back to the production. There is also the pressure to develop the no-waste-production. The recycling and way to the no-waste-production is very popular and the research how to recycle and reuse old building materials or waste from production is running. Very popular is recycling of concrete, or using of recycled materials for concrete as a filler. The greater interest in this material is due to the large use of concrete in construction. The observation of the influence on mechanical properties in this area can be found in many researches by J. Topič, P. Tesárek et al. 3], 4], [5].

There is not only concrete in construction and for example gypsum based building materials are very popular for their properties and it is necessary to deal with this issue. Gypsum products have a relatively low bulk density, which ranges from $600-1200 \mathrm{~kg} \mathrm{~m}^{-3}$, which is about half the bulk density of conventional concrete. This feature allows easy handling of products during construction and the another advantage is less load on the building structure.

Gypsum is used for its properties in fire protection construction. The gypsum looses during effect of high temperature crystal bound water. This water makes the fire protection of the construction, because 
it decreases the temperature of the surface of the construction [6].

The another positive property of gypsum is that it is hygroscopic. It means, the rehydrated gypsum can absorb the air humidity. It is the regulator of humidity in living space, what brings comfort feeling in rooms. The volume changes are relative low during this process $[7$.

\section{MATERIAL}

The materials, which were used for these experiments, were the white stucco and the waste material from two sources. The white stucco is calcinated of FGD gyspsum. The FGD gypsum is produced during the desulphurisation process flue gases in power plant, where is burned the brown coal. This FGD gypsum has very high level of purity (96\% on average). The white stucco calcinated of FGD gypsum is used as main material in production of plaster boards and gypsum plasters. These materials are showed on Figure 1. The first option of waste material were the gypsum based blocks. The second option of waste material were the plaster boards (PB). Both of these waste materials were crushed and milled. In the case of boards there was separated the paper above that and the grains were less fine than the grains of milled gypsum blocks. The crushing, milling and separating was done on Lavaris equipment. Figure 3 shows the material after primer crusher. This material included both of main parts of plaster boards - gypsum core and paper. Figure 4 shows material without paper. The paper was separated and the gypsum material is ready for sorting. The fine milled material and paper are showed on Figure 2

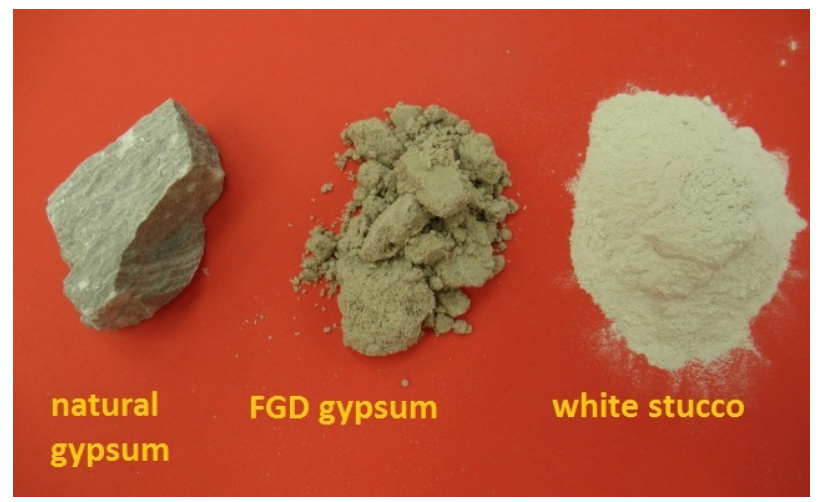

Figure 1. Natural and FGD gypsum, stucco.

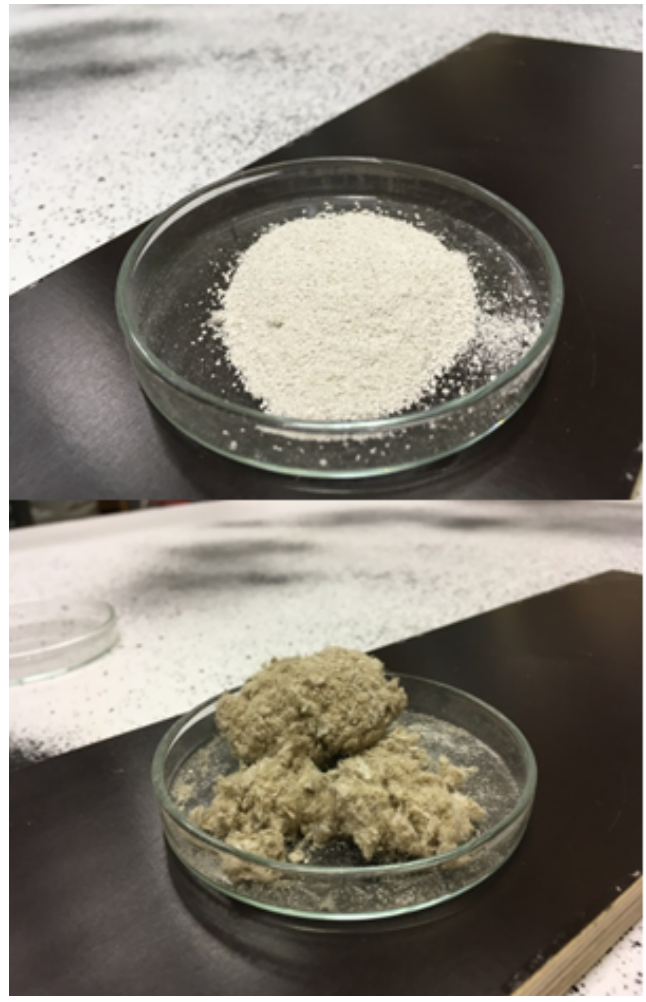

Figure 2. Fine milled gypsum and separated paper.

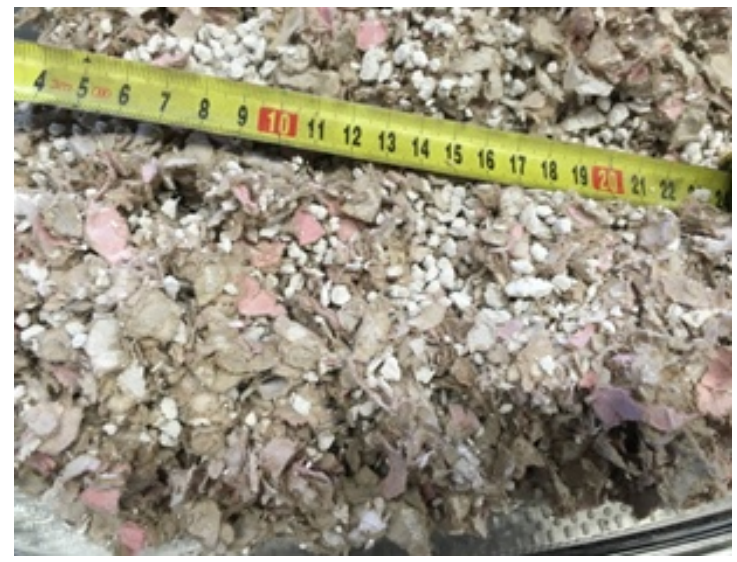

Figure 3. Crushed plaster boards with paper.

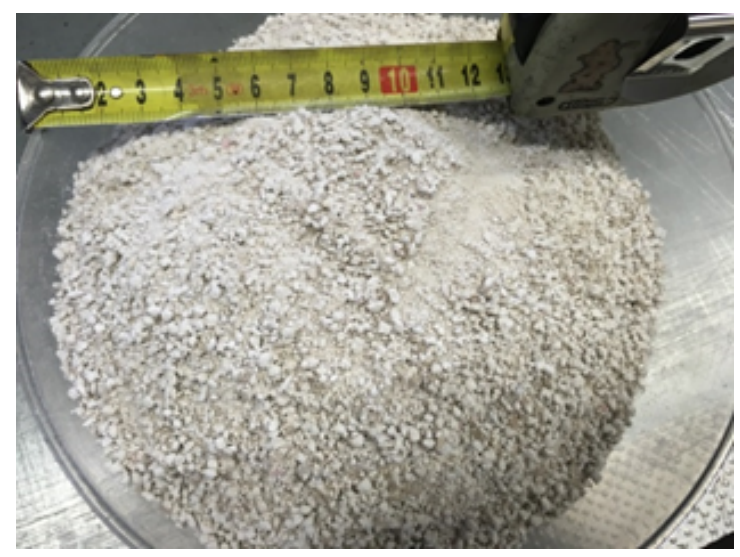

Figure 4. Milled gypsum before sorting and without paper. 


\begin{tabular}{ccccc}
\hline $\begin{array}{c}\text { Amount of stucco } \\
\text { [\% wt.] }\end{array}$ & $\begin{array}{c}\text { Amount of recycled material } \\
{[\% \text { wt.] }}\end{array}$ & $\begin{array}{c}\text { Initial time } \\
{[\mathrm{min}]}\end{array}$ & $\begin{array}{c}\text { Final time } \\
{[\mathrm{min}]}\end{array}$ & $\begin{array}{c}\text { Splash } \\
{[\mathrm{mm}]}\end{array}$ \\
\hline 90 & 10 & 1 & 2 & 50 \\
75 & 25 & 2 & 2 & 56 \\
50 & 50 & 12 & $>2$ weeks & 58 \\
10 & 90 & $>2$ weeks & $>2$ weeks & 61 \\
\hline
\end{tabular}

TABLE 1. Basic properties.

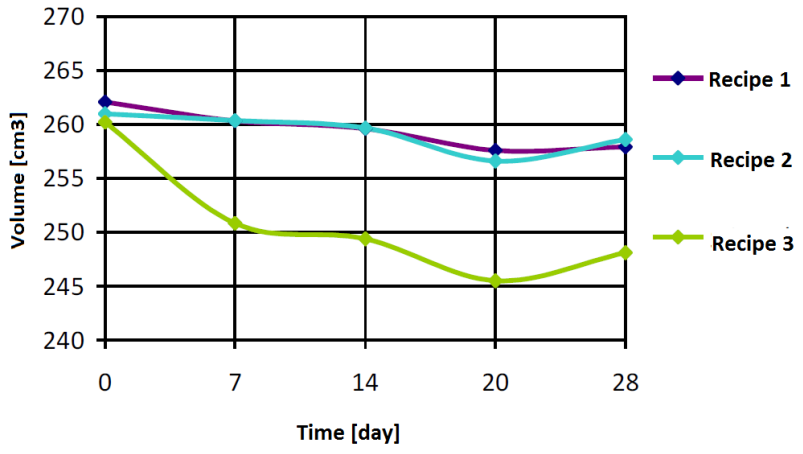

FIGURE 5. Volume changes over time - recycled blocks 8 .

\subsection{THE EFFECT OF RECYCLED MATERIAL ON BASIC PROPERTIES}

In the first step was observed the behaviour the gypsum slurry depending on the amount of recycled material in recipe. The slurry was mixed by hand without any equipment. The water ratio was in each of recipe 1.2. There were observed the setting times (initial time IS and final time FS) and the diameter of splash. The results are showed in Table 1 These results showed, that the $50 \%$ is the maximal amount of recycled material, which is possible to use for preparing of samples for following tests. The bigger amount leads to loose of solidifying ability.

\subsection{THE EFFECT OF RECYCLED MATERIAL ON VOLUME CHANGES}

The volume changes was observed on prisms $160 \times$ $40 \times 40 \mathrm{~mm}$. There were prepared 3 different recipes for each recycled material, which were selected in first part of experiment. The recipe 1 is reference sample of pure white stucco. The recipe 2 is $90 \%$ of white stucco and $10 \%$ of milled blocks. The recipe 3 is $75 \%$ of white stucco and $25 \%$ of milled blocks. The recipe 4 is $90 \%$ of white stucco and $10 \%$ of milled plaster boards (PB). The recipe 5 is $75 \%$ of white stucco and $25 \%$ of milled plaster boards and the Recipe 6 is $50 \%$ of white stucco and $50 \%$ of milled plaster boards. All presented $\%$ are $\%$ wt. There were prepared 3 samples of each recipe. All of this samples are tested and the average value for each recipe was signed. The prism were measured and weighed over the next 28 days. The samples lost the free moisture (weight loss) and the volume shrinkage could be monitored too. The results are showed in Figures 5 and 6

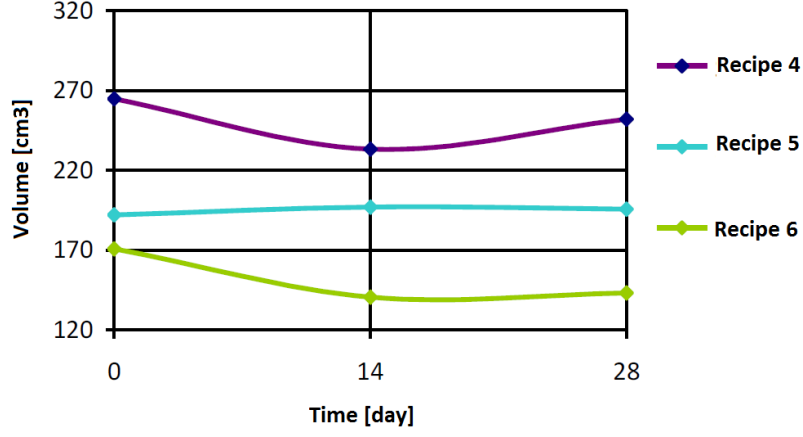

FIGURE 6. Volume changes over time - recycled plaster boards [8].

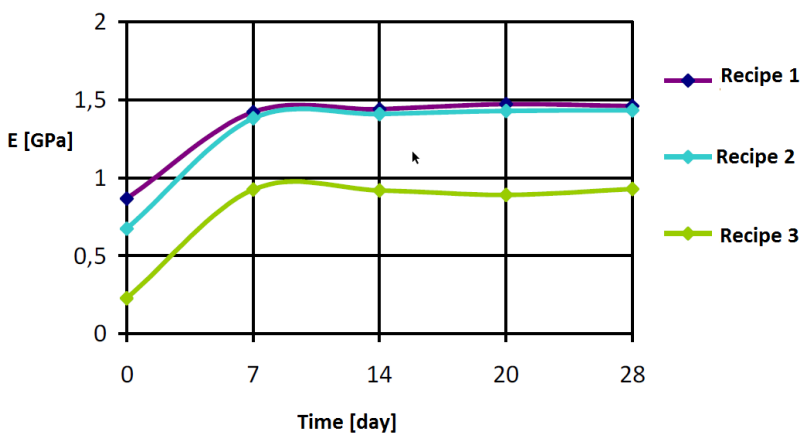

FiguRe 7 . Volume changes over time - recycled plaster boards [8].

\section{EXPERIMENTAL METHODS AND RESULTS}

The shrinkage increased depending on the amount of recycled material. This is because in the samples with more recycled material is more free water, which is not included in crystal bonded water.

\subsection{Changes of Elasticity module over TIME}

The prisms prepared for the observed volume changes (Recipes 1-3) was used also for observed changes of elasticity module. This property was tested by nondestructive method - Modal analysis. The elasticity module was counted on the base of resonant frequency of samples. The measurement was carried out with a impulse hammer with sensor which was linked to software that processed the values of frequencies and after that was possible to count the elasticity module 8 The course of results is showed on Figure 7 The elasticity module is increases over time. It depends on 


\begin{tabular}{ccccccc}
\hline $\begin{array}{c}\text { Recipe } \\
{[\mathrm{Nr} .]}\end{array}$ & $\begin{array}{c}\text { Content } \\
\text { stucco } \\
{[\% \text { wt. }]}\end{array}$ & $\begin{array}{c}\text { milled blocks } \\
{[\% \text { wt. }]}\end{array}$ & $\begin{array}{c}\text { milled PB } \\
{[\% \text { wt. }]}\end{array}$ & $\begin{array}{c}\text { Water ratio } \\
{[-]}\end{array}$ & $\begin{array}{c}\text { Flexural } \\
\text { strength } \\
{[\mathrm{MPa}]}\end{array}$ & $\begin{array}{c}\text { Compressive } \\
\text { strength } \\
{[\mathrm{MPa}]}\end{array}$ \\
\hline 1 & 100 & 0 & 0 & 1.4 & 16.85 & 2.06 \\
2 & 90 & 10 & 0 & 1.4 & 11.47 & 0.63 \\
3 & 75 & 25 & 0 & 1.4 & 6.79 & 0.13 \\
4 & 90 & 0 & 10 & 1.2 & 17.55 & 0.97 \\
5 & 75 & 0 & 25 & 1.2 & 21.53 & 1.48 \\
6 & 50 & 0 & 50 & 1.2 & 25.04 & 1.92 \\
\hline
\end{tabular}

TABLE 2. Flexural and Compressive strength.

lost of free and bounded moisture from the samples. The gypsum core is more compact and stronger. The bigger shrinkage leads to higher values of elasticity module.

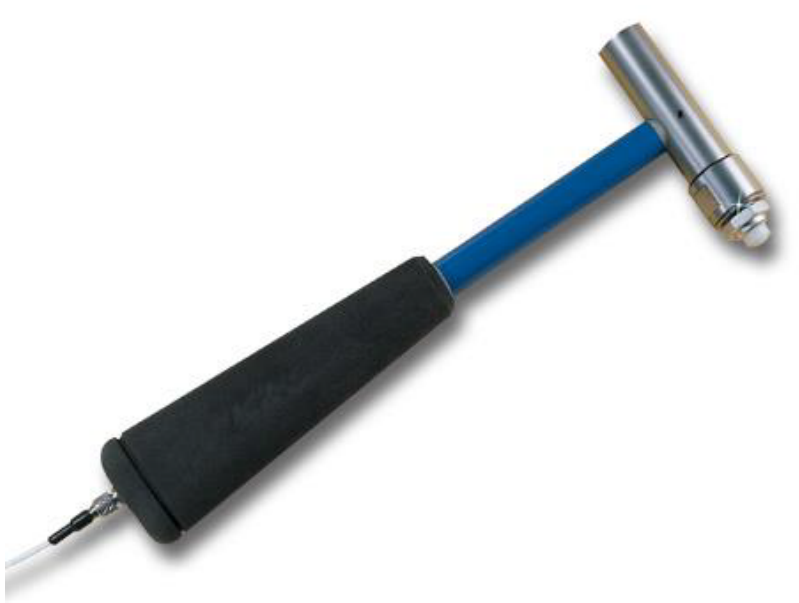

Figure 8. Impulse hammer [9].

\subsection{Strength Destructive Methods}

The prisms were used in the end of this particular research for destructive strength tests. The both tests were executed according to standard ČSN 722301. The flexural strength is the first part of the test. The test method is a three point flexural test technique and the flexural strength represents the highest stress experienced within the material at its moment of yield 9 The compressive strength test is performed on parts of samples after execution a three point flexural test technique. The force of the machine act at the whole surface of the sample 10

The results are showed in Table 2. The decrease of values of Compressive strength depending on the increasing amount of milled blocks are completely different from increase of these values depending on the increasing amount of milled plaster boards. The low breaking loads are caused by high content of water in gypsum slurry. The high water ratio was used because of bad consistency of slurry, which was with lower water ratio unprocessable.

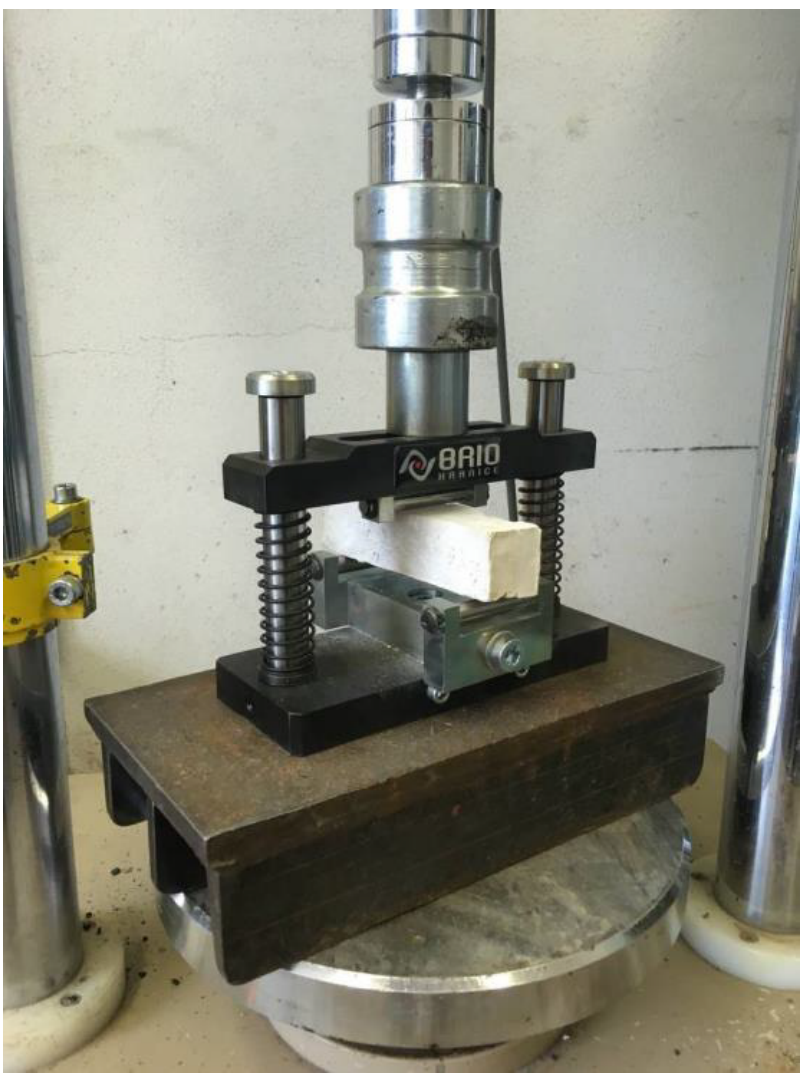

Figure 9. Three point flexural test technique [8].

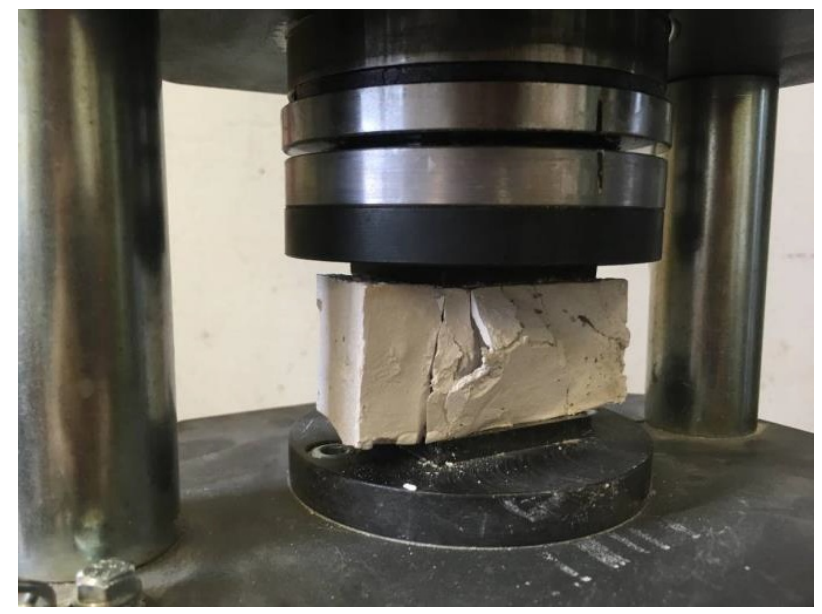

Figure 10. Compressive strength test 8 . 


\section{Conclusions}

This research found in its very early begins several dependencies in behaviour the gypsum samples which were prepared with a gypsum based recycled materials. That showed that it is very important to find optimal water ratio. Optimal consistency of gypsum slurry is necessary to get the gypsum product with the best properties. In practice is usually use the liquifiers, accelerators or retarders to optimize gypsum slurry properties. The optimal water ratio for the gypsum slurry is from 0.6 to 0.8 . In these test was necessary to use the water ratio higher, because we used fine milled material which accelerates the solidifying reaction. The fine grain worked as a crystallization nucleus and the reaction was very fast and in this case was reaction slowed down by adding more water. It optimized the process of rehydration, but it brought the decrease the other properties which were tested. They depend on the structure of gypsum core and when the gypsum slurry contents too much water it generates more pores in volume of gypsum based products and this leads to a reduction in strength and bigger volume changes over time. On the other hand it brings also better thermal properties.

\section{ACKNOWLEDGEMENTS}

This paper was based on research supported by grant MPO Trio č. FV30359, where cooperate CTU in Prague, Faculty of Civil Engineering, Lavaris s.r.o. and Knauf Praha spol. s r.o.

\section{REFERENCES}

[1] P. Rovnaníková, Z. Keršner. Vlastnosti modifikované sádry. first printing. Vysoké učení technické v Brně, Akademické nakladatelství CERM, s.r.o., Brno, 2009.

[2] V. Pačes. Budoucnost energetiky očima odborníků. [2019-07-15], https://www. siemens.cz/energo/ budoucnost-energetiky-ocima-odborniku.
[3] J. Topič, Z. Prošek. Properties and microsture of cement paste including recycled concrete powder. Acta Polytechnica 57(1):49-57, 2017.

[4] P. Tesárek, K. Šeps, J. Topič, et al. Influence of recycled materials on resulting mechanical properties of cement composites. Modern Methods of Experimental and Computational Investigations in Area of Construction 825:53-56, 2016. DOI:10.4028/www.scientific.net/AMM.825.53.

[5] J. Topič, Z. Prošek, J. Hrůza. Mechanical properties of cement paste with fine ground recycled concerete depending on the microstructure. Modern Methods of Experimental and Computational Investigations in Area of Construction II 1144:22-27, 2017. DOI:10.4028/www.scientific.net/AMR.1144.22

[6] A. Vimmrová, L.Svoboda. Stavební hmoty Vápenosíranová pojiva. first printing. Jaga group, s.r.o., Bratislava, 2004.

[7] W. Schulze. Necementové malty a betony. first printing. SNTL, Praha, 1990.

[8] J. Herrmann. Možnosti recyklace výrobků na bázi sádry, 2019.

https://dspace.cvut.cz/bitstream/handle/10467/ 84255/F1-DP-2019-Herrmann-Jakub-DP_Herrmann _ bez $\% 20$ podpisu.pdf? sequence $=-1 \&$ is Allowed $=y$.

[9] OMEGA-Engineering, 2019. https://in.omega.com/pptst/IH101.html 